\title{
EFFECT OF NITROGEN ON YIELD, YIELD COMPONENTS AND CONTRIBUTION FROM THE PRE-ANTHESIS ASSIMILATES TO GRAIN YIELD OF THREE PHOTOSENSITIVE RICE (ORYZA SATIVA L.) CULTIVARS
}

\author{
N. AHMED ${ }^{1}$, M. EUNUS ${ }^{2}$, M.A. LATIF ${ }^{1}$, Z.U. AHMED ${ }^{1}$, and M. RAHMAN ${ }^{1}$ \\ ${ }^{1}$ Bangladesh Rice Research Institute, Gazipur 1701, Bangladesh. \\ 2 Department of Agronomy, Bangladesh Agricultural University, Mymensingh-2202, \\ Bangladesh.
}

(Received: 13 August 1997; accepted: 06 February 1998)

\begin{abstract}
The experiment was conducted in the Agronomy field laboratory of Bangladesh Agricultural University to find out the pre-anthesis contribution to grain yield in selected rice varieties (BR22,BR23 and Nizersail) of Bangladesh. Total tiller no. $/ \mathrm{m}^{2}$, no. of effective tillers $/ \mathrm{m}^{2}$, spikelet no./panicle, \% filled grain, 1000 grain wt, straw yield and grain yield varied significantly in different cultivars. Grain yield was highes in BR23 (5.08 t/ha) followed by BR22 (4.59 t/ ha). Levels of $\mathrm{N}$ significantly influenced all the crop characters studied except 1000 grain wt. Increasing $\mathrm{N}$ level increased grain and straw yield. The interaction effect between cultivar and $\mathrm{N}$ was significant for effective tiller no./ $\mathrm{m}^{2}$, spikelet no./panicle, \% filled grain, grain yield and \% contribution to grain yield from pre-anthesis assimilates. Pre-anthesis assimilate contribution to grain yield was greatest with no $\mathrm{N}$ application (28\% in BR22 and BR23), and was lowest at $120 \mathrm{~kg} \mathrm{~N} / \mathrm{ha}$ ( $3 \%$ in Nizersail). The pre-anthesis assimilate contribution showed a negative relationship with increased $\mathrm{N}$ application. However, this relationship varied for different cultivars with BR 23 showing a greater capacity to mobilize pre -anthesis assimilates than BR22 and Nizersail.
\end{abstract}

Key words: Grain yield, nitrogen, Oryza sativa L., pre-anthesis assimilates, rice.

\section{INTRODUCTION}

Nitrogen is the key nutrient element, representing two-thirds or more of the total nutrient consumption in Asia. ${ }^{1}$ The amount of $\mathrm{N}$ that a rice plant absorbs to produce a unit of grain yield is nearly constant at $19-21 \mathrm{~kg}$ N/t brown rice. Accordingly the plant must absorb a larger amount of $\mathrm{N}$ to produce a higher grain yield. ${ }^{2}$

For maximization of rice yield, proper agronomic management is very important. Among the management practices, soil fertilization, particularly nitrogen management is the most important. High yielding varieties (HYVs) are generally more responsive to nitrogen application and they show increased yield with increasing nitrogen level up to a certain limit. The yield of Transplant Aman rice (usually grown in the wet season, i.e from July to December) is lower than Boro rice (usually grown in the dry season i.e. from January to April) 
because of higher temperatures in the early stage and lower temperatures in the latter stages and also because of the lower response to fertilizer, especially N.

Transplanting Aman growing environment in Bangladesh represents the rainfed lowland rice (RLR) culture. The photosensitive group of rice varieties are grown in this ecosystem during the above mentioned period. High yielding varieties (HYVs) of rice cover about $40 \%$ of RLR area ${ }^{3}$ in Bangladesh. Hence, $60 \%$ of the rice area is still planted with local photosensitive varieties (PS) even 20 years after HYV rice was introduced. In the wet season, only $24 \%$ HYVs are cultivated by the farmers. ${ }^{4}$

Grain yield of any cereal is determined by the dry matter produced before and after anthesis. Pre-anthesis assimilation varies with cultivars, availability of inputs, such as irrigation and fertilizers, weed and disease infestation. ${ }^{6}$

The assimilates stored in rice grain during ripening originate from two sources. ${ }^{7}$ One is the pre-heading assimilates which are subsequently transferred to the grain during the ripening period. The other is the assimilates produced during the ripening period. Pre-anthesis assimilates may provide a significant contribution to the grain yield. However, information of pre-anthesis assimilates contribution to grain yield of rice under different $N$-doses during wet season in Bangladesh is not available. Therefore, the objective of this experiment was to examine the effect of pre-anthesis contribution to grain yield of three rice varieties under five $\mathrm{N}$-levels.

\section{METHODS AND MATERIALS}

Two high-yielding and one local photosensitive varieties viz. BR22, BR23 and Nizersail were transplanted in the Agronomy field laboratory, Bangladesh Agricultural University, Mymensingh, Bangladesh during Transplanted Aman season, 1992. The experimental site was a medium highland (many places of the area remain submerged upto 6-8 months of the year by $1.8-2.5 \mathrm{~m}$ water) with sandy loam texture having $\mathrm{pH} 6.65$, organic matter $2.44 \%$, total $\mathrm{N} 0.115 \%$, available $\mathrm{P}$ (Olsen) $21.0 \mathrm{ppm}$ and exchangeable $\mathrm{K} 0.43 \mathrm{meq} / 100 \mathrm{~g}$ soil which belongs to Order Inseptisol as per 7th approximation by USDA. Phosphorus, potassium, sulphur and zinc fertilizer were applied through triple superphosphate, muriate of potash, gypsum, and zinc sulphate at the rates of $90 \mathrm{~kg} / \mathrm{ha}, 40$ $\mathrm{kg} / \mathrm{ha}, 60 \mathrm{~kg} / \mathrm{ha}$ and $10 \mathrm{~kg}$.ha, respectively, as per recommendation of BRRI. ${ }^{8}$ All the phosphate, potassium, sulphur and zinc fertilizers and one-third of urea were applied in each plot at the time of final land preparation and were mixed thoroughly with soil. The rest two-thirds of urea was top-dressed in two equal splits, i.e.. one at active tillering stage and the other at panicle initiation stage at 30 and 55 days after transplanting respectively. The control plots received 
no nitrogen fertilizer. The experiment was laid out in split-plot design with four replications in a $5 \times 4 \mathrm{~m}^{2}$ plot, spaced at $25 \times 15 \mathrm{~cm}$ using two seedlings/hill. Levels of nitrogen were $0,60,80,100,120 \mathrm{~kg} / \mathrm{ha}$. Main plot and subplot treatments were variety and levels of nitrogen respectively. Grain yield was measured at maturity by harvesting $5 \mathrm{~m}^{2}$ from the centre of each plot. Yield components were recorded from 10 randomly selected hills from each plot.

Stem weight at anthesis was recorded by harvesting an area of $0.25 \mathrm{~m}^{2}$ in each plot. The stems including leaves were dried at $85^{\circ} \mathrm{C}$ for 24 hours and weighed separately. At pre-anthesis, stems were weighed together with leaves since leaves contributed little to grain yield from pre-anthesis assimilation. ${ }^{9}$ Yoshida \& Ahn ${ }^{10}$ reported that the change in carbohydrate content of leaf blades, sheath and culm could account for upto $38 \%$ of grain carbohydirate and that the contribution varied considerably among varieties in rice. Contribution from preanthesis assimilate to grain yield was calculated according to Gallagher et al. ${ }^{11}$ and also as suggested by Sadeque. ${ }^{12}$

Pre-anthesis contribution to grain yield

Stem weight at anthesis - stem weight at maturity

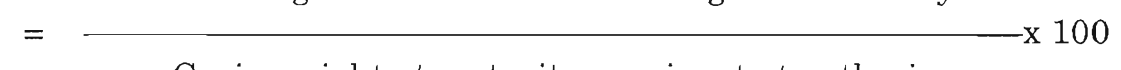

Grain weight at maturity - grain wt at anthesis

The data were analysed following standard statistical procedures. ${ }^{13}$

\section{RESULTS AND DISCUSSION}

\section{Number of Tillers $/ \mathrm{m}^{2}$}

Total tillers $/ \mathrm{m}^{2}$ at harvest was markedly influenced by $\mathrm{N}$ (Table $1 \& 2$ ), indicating a positive linear relationship between tiller number to added No ( $\mathrm{Y}=201.5$ $+0.45 \mathrm{X}, \mathrm{R}^{2}=0.93^{*}$ ) within the range of $\mathrm{N}$ levels used. The tiller no. $/ \mathrm{m}^{2}$ was significantly higher at $120 \mathrm{~kg} \mathrm{~N} / \mathrm{h}$ a than at lower N levels. Among the varieties, BR22 produced the highest tillers $/ \mathrm{m}^{2}$. The difference was significantly higher $(\mathrm{p}<0.05)$ than BR23 and Nizersail. Jashim et $a l^{14}$ also reported similar results for tiller production in rice.

\section{Number of Panicles $/ \mathrm{m}^{2}$}

Panicle $/ \mathrm{m}^{2}$ increased significantly with the increase of $\mathrm{N}$ supply (Table $1 \& 2$ ), but the varietal response to $\mathrm{N}$ was not similar. Panicles $/ \mathrm{m}^{2}$ of BR22 and BR23 increased significantly at higher rate of added $\mathrm{N}$. In the case of Nizersail it increased up to $80 \mathrm{~kg}$ N/ha , then decreased. BR22 produced more panicles $/ \mathrm{m}^{2}$ than BR23 and Nizersail The results were consistent with those of Awan et al. ${ }^{15}$ who reported that increased panicle number was due to $\mathrm{N}$ fertilizer. 
Table 1: Effect of cultivar and $\mathrm{N}$ on yield components of rice during $\mathrm{T}$. Aman season, 1992.

\begin{tabular}{llllll}
\hline Treatment & $\begin{array}{l}\text { No. of } \\
\text { tillers } / \mathrm{m}^{2}\end{array}$ & $\begin{array}{l}\text { No. of } \\
\text { Panicles } \\
\end{array}$ & $\begin{array}{l}\text { No. of } \\
\text { Spikelets } \\
\text { /panicle }\end{array}$ & $\begin{array}{l}\text { Filled } \\
\text { grain } \\
(\%)\end{array}$ & $\begin{array}{l}1000 \\
\text { grain } \\
\text { weight } \\
(\mathrm{g})\end{array}$
\end{tabular}

\section{Cultivar}

$\begin{array}{llllll}\text { BR22 } & 275.6 \mathrm{a} & 243.1 \mathrm{a} & 126.2 \mathrm{~b} & 85.17 \mathrm{~b} & 18.94 \mathrm{~b} \\ \text { BR23 } & 250.9 \mathrm{~b} & 219.7 \mathrm{~b} & 145.5 \mathrm{a} & 85.57 \mathrm{a} & 25.13 \mathrm{a} \\ \text { Nizersail } & 256.1 \mathrm{~b} & 189.8 \mathrm{c} & 121.6 \mathrm{c} & 83.10 \mathrm{c} & 16.55 \mathrm{c}\end{array}$

\section{$\mathrm{N}(\mathrm{kg} / \mathrm{ha})$}

\begin{tabular}{llllll}
0 & $212.3 \mathrm{~d}$ & $182.0 \mathrm{e}$ & $112.1 \mathrm{a}$ & $80.80 \mathrm{~d}$ & $19.57 \mathrm{~b}$ \\
60 & $249.2 \mathrm{c}$ & $214.5 \mathrm{~d}$ & $126.6 \mathrm{~d}$ & $85.04 \mathrm{c}$ & $20.26 \mathrm{~b}$ \\
80 & $268.7 \mathrm{~b}$ & $229.7 \mathrm{~b}$ & $133.2 \mathrm{c}$ & $85.95 \mathrm{a}$ & $20.09 \mathrm{ab}$ \\
100 & $275.2 \mathrm{~b}$ & $225.3 \mathrm{c}$ & $139.3 \mathrm{~b}$ & $85.88 \mathrm{a}$ & $20.11 \mathrm{ab}$ \\
120 & $299.0 \mathrm{a}$ & $236.2 \mathrm{a}$ & $149.3 \mathrm{a}$ & $85.40 \mathrm{~b}$ & $21.00 \mathrm{a}$ \\
\hline
\end{tabular}

In a column, means followed by a common letter are not significantly different at $5 \%$ level by DMRT.

\section{Number of Spikelets /panicle}

Table 1 shows that spikelets /panicle in all rice varieties increased significantly as the $\mathrm{N}$ level increased, showing a positive significant linear relation between spikelets/panicle to added $\mathrm{N}\left(\mathrm{Y}=111.6+0.27 \mathrm{X}, \mathrm{R}^{2}=0.996^{*}\right)$ within the range of $\mathrm{N}$ levels used. In all rice varieties the highest no. of spikelets/panicle was observed at $120 \mathrm{~kg} \mathrm{~N} / \mathrm{ha}$. Spikelets/panicle was significantly different between the varieties. BR 23 produced higher spikelets / panicle than the other two varieties. Lower spikelets/panicle in Nizersails was one of the factors responsible for lower grain yield (Tables 1 and 2). The results were similar to those of Dixit \& Singh ${ }^{16}$ who reported higher spikelets/panicle with higher levels of added $N$.

\section{Filed grain percentage}

Similar to spikelet production, filled grain percentage increased significantly due to added $\mathrm{N}$ (Tables 1 and 2). However, in all varieties increases were significant only in the $0-60 \mathrm{~kg} N /$ ha range. Similar results were reported by Chandranath et al. ${ }^{17}$ and Jennyc. ${ }^{18}$ The percentage of filled grain spikelet is highly affected by variety, $\mathrm{N}$ management, soil and climate. ${ }^{19}$ 
Table 2: Effect of interaction between cultivar and $\mathrm{N}$ on yield components of rice during T. Aman season ,1992.

Plant Characters Nitrogen level (kg/ha)

Variety

BR22 BR23 Nizersail

No. of tillers $/ \mathrm{m}^{2}$

$\begin{array}{rlll}0 & 227.5 \mathrm{cA} & 201.5 \mathrm{~dB} & 208.0 \mathrm{cAB} \\ 60 & 266.5 \mathrm{bA} & 234.0 \mathrm{cB} & 247.0 \mathrm{bAB} \\ 80 & 279.5 \mathrm{bA} & 253.5 \mathrm{bA} & 273.0 \mathrm{aA} \\ 100 & 286.0 \mathrm{bA} & 266.5 \mathrm{bA} & 273.0 \mathrm{aA} \\ 120 & 318.5 \mathrm{aA} & 299.0 \mathrm{aA} & 279.5 \mathrm{aB}\end{array}$

No. of Panicles $/ \mathrm{m}^{2}$

$\begin{array}{rlll}0 & 201.5 \mathrm{cA} & 175.5 \mathrm{~dB} & 169.0 \mathrm{cB} \\ 60 & 234.0 \mathrm{bA} & 208.0 \mathrm{cB} & 201.5 \mathrm{abB} \\ 80 & 247.0 \mathrm{bA} & 221.0 \mathrm{bcB} & 221.0 \mathrm{aB} \\ 100 & 253.5 \mathrm{bA} & 234.0 \mathrm{bA} & 188.5 \mathrm{bB} \\ 120 & 279.5 \mathrm{aA} & 260.0 \mathrm{aA} & 169.0 \mathrm{cB}\end{array}$

No. of Spikelets/Panicle

$\begin{array}{rlll}0 & 108.3 \mathrm{eB} & 124.0 \mathrm{bA} & 109.0 \mathrm{eC} \\ 60 & 122.5 \mathrm{~dB} & 139.8 \mathrm{dA} & 117.5 \mathrm{dC} \\ 80 & 126.8 \mathrm{cB} & 149.0 \mathrm{cA} & 123.8 \mathrm{cC} \\ 100 & 133.8 \mathrm{bB} & 154.3 \mathrm{bA} & 130.0 \mathrm{bC} \\ 120 & 139.8 \mathrm{aB} & 160.5 \mathrm{aA} & 132.5 \mathrm{aC}\end{array}$

Filled grain (\%)

$\begin{array}{rlll}0 & 81.7 \mathrm{~dB} & 79.6 \mathrm{eC} & 81.8 \mathrm{dA} \\ 60 & 85.0 \mathrm{cB} & 85.9 \mathrm{dA} & 84.2 \mathrm{bC} \\ 80 & 86.2 \mathrm{bA} & 86.4 \mathrm{cA} & 85.3 \mathrm{aB} \\ 100 & 86.8 \mathrm{aB} & 87.7 \mathrm{bA} & 83.2 \mathrm{cC} \\ 120 & 86.8 \mathrm{aB} & 88.3 \mathrm{aA} & 81.1 \mathrm{eC}\end{array}$

1000 grain wt. (g)

\begin{tabular}{rlll}
0 & $17.75 \mathrm{bB}$ & $24.64 \mathrm{aA}$ & $16.31 \mathrm{aB}$ \\
60 & $18.65 \mathrm{bB}$ & $25.42 \mathrm{aA}$ & $16.71 \mathrm{aB}$ \\
80 & $18.13 \mathrm{bB}$ & $25.55 \mathrm{aA}$ & $16.58 \mathrm{aB}$ \\
100 & $18.96 \mathrm{bB}$ & $24.85 \mathrm{aA}$ & $16.52 \mathrm{aC}$ \\
120 & $21.19 \mathrm{aB}$ & $25.20 \mathrm{aA}$ & $16.63 \mathrm{aC}$ \\
\hline
\end{tabular}

Means in columns and rows followed by the same letter(s) are not significantly different at $5 \%$ level by DMRT. Lower case and capital letters indicate comparison within column and row respectively. 


\section{0 grain weight $(\mathrm{g})$}

$\mathrm{N}$ at varying levels had no significant effect on 100 grain weight in all rice varieties except BR22. In BR22 the 1000 grain weight is significantly greater at $120 \mathrm{~kg}$ N/ha. However, 1000 grain weight of BR22 and BR23 was significantly higher than that of Nizersail (Tables 1 and 2). Tanaka et al ${ }^{20}$ reported a decrease in 1000 grain weight with increasing $\mathrm{N}$ supply, particularly in traditional varieties.

\section{Grain yield}

Both grain and straw yield increased progressively with increased $\mathrm{N}$ level in a].] rice varieties tested (Table 3). Grain yield response to added nitrogen was identical among the high and low yielding varieties within the range of $\mathrm{N}$ levels tested. A positive linear relationship existed between grain yield and added $\mathrm{N}$ in BR23 ( $\left.\mathrm{Y}=3.39+0.024 \mathrm{~N}, \mathrm{R}^{2}=0.99^{*}\right)$ and BR22 $\left(\mathrm{Y}=2.40+0.297 \mathrm{~N}, \mathrm{R}^{2}=0.95^{*}\right)$. In both these high yielding varieties, grain yield responded linearly up to $120 \mathrm{~kg} \mathrm{~N} /$ ha, while in Nizersail, $\mathrm{N}$ response in terms of grain yield was curvilinear. $\left(\mathrm{Y}=2.76+0.0265 \mathrm{~N}-0.0002 \mathrm{~N}^{2}, \mathrm{R}^{2}=0.9863^{\circ}\right)$ with the grain yield increasing up to $60 \mathrm{~kg}$ N/ha and decreasing subsequently,. Many investigators have reported that grain yield of rice increased due to N. ${ }^{4,21,22}$

Table 3: Effect of cultivar and N on \% pre-anthesis contribution of rice during T. Aman season, 1992.

\begin{tabular}{ccccc} 
Treatment & $\begin{array}{c}\text { Stem wt. at } \\
\text { anthesis (t/ha) }\end{array}$ & $\begin{array}{c}\text { Straw yield at } \\
\text { harvest (t/ha) }\end{array}$ & $\begin{array}{c}\text { Grain yield } \\
(\mathrm{t} / \mathrm{ha})\end{array}$ & $\begin{array}{c}\text { Pre-anthesis } \\
\text { contribution }(\%)\end{array}$ \\
\hline
\end{tabular}

\section{Cultivar}

$\begin{array}{llllr}\text { BR22 } & 6.38 \mathrm{~b} & 5.82 \mathrm{~b} & 4.59 \mathrm{~b} & 14.52 \mathrm{~b} \\ \text { BR23 } & 7.38 \mathrm{a} & 6.60 \mathrm{a} & 5.08 \mathrm{a} & 17.01 \mathrm{a} \\ \text { Nizersail } & 6.63 \mathrm{~b} & 6.39 \mathrm{a} & 3.08 \mathrm{c} & 7.81 \mathrm{c}\end{array}$

\section{N (kg/ha)}

\begin{tabular}{llllr}
0 & $5.02 \mathrm{~d}$ & $4.34 \mathrm{e}$ & $2.93 \mathrm{~d}$ & $23.07 \mathrm{a}$ \\
60 & $6.11 \mathrm{c}$ & $5.46 \mathrm{~d}$ & $4.02 \mathrm{c}$ & $15.73 \mathrm{~b}$ \\
80 & $7.00 \mathrm{~b}$ & $6.22 \mathrm{c}$ & $4.45 \mathrm{~b}$ & $16.32 \mathrm{~b}$ \\
100 & $7.52 \mathrm{~b}$ & $7.16 \mathrm{~b}$ & $4.72 \mathrm{~b}$ & $7.17 \mathrm{c}$ \\
120 & $8.33 \mathrm{a}$ & $8.16 \mathrm{a}$ & $5.04 \mathrm{a}$ & $3.27 \mathrm{~d}$ \\
\hline
\end{tabular}

In a column, means followed by a common letter are not significantly different at the $5 \%$ level by DMRT. 


\section{Straw yield}

Similar to grain yield, straw yield in all rice varieties tested increased significantly due to $\mathrm{N}$ fertilization. Highest straw yield was observed at $120 \mathrm{~kg} \mathrm{~N} / \mathrm{ha}$ (Tables 3 and 4). Among the varieties, BR23 and Nizersail produced significantly greater straw yield than BR22. The results agreed with those of Eaqub et $a l .{ }^{23}$ and other workers. ${ }^{4.22}$

\section{Pre-anthesis assimilate contribution to grain yield}

BR23 had a significantly greater stem weight at anthesis than BR22 and Nizersail (Table 3). Application of nitrogen increased stem weight at anthesis. This response was linear $\left(Y=4.832+0.0273 \mathrm{X}, \mathrm{R}^{2}=0.97^{*}\right)$ within the range of $\mathrm{N}$ levels tested. This result corroborates with BRRI's findings (BRRI $1992^{22}$ and $1993^{4}$ ). These values correspond well with the values of stem weight at maturity and with those of stem and grain weight between anthesis and maturity (Tables 3 and 4).

Calculations have shown" that cultivar and levels of nitrogen significantly influenced the extent of pre-anthesis assimilate contribution to grain yield. The contributions from different cultivars to grain yield from pre-anthesis assimilation were $17.01 \%$ in BR23, $14.52 \%$ in BR22 and $7.81 \%$ in Nizersail (Tables 3 \& 4). BR23 performed better with respect to stem contribution and grain yield than that of BR22 and Nizersail. Weng et al. ${ }^{7}$ and Vorob'ev and Skazheinnik ${ }^{24}$ reported similar results. The interaction effect between cultivar and nitrogen was significant on per cent contribution from pre-anthesis assimilation to grain yield (Table 4). The highest contribution was $28.20 \%$ in BR22 with no nitrogen. This decreased gradually due to $\mathrm{N}$ and the same trend was observed in Nizersail beginning with $12.9 \%$ contribution of stem to grain. In BR23, highest contribution was $28 \%$ with no nitrogen which did not signifjcantly differ with the contribution at $80 \mathrm{~kg}$ N/ha. Overall results showed that the pre-anthesis assimilate contribution was highly negatively correlated with increased nitrogen rates $\left(Y=24.669-0.160 X, R^{2}=0.88^{\circ}\right)$. These results were supported by Prabakar et al. ${ }^{25}$ Vorob'ev and Shazheinnik ${ }^{24}$ and Balkema-Boomstra. ${ }^{26}$ In this study, the calculated values of pre-anthesis assimilate contribution to grain. yield were higher than expected in a normal growing environment of the crop. However, these levels were within reasonable limits as reported by Gallagher et al. ${ }^{11}$ and Gent. ${ }^{6}$ Another possible explanation for higher values was that in this calculation proposed by Gallagher et al., ${ }^{11}$ respiratory losses are not taken into account.

Results revealed that cultivars responded differently to applied $\mathrm{N}$ for preanthesis assimilate contribution to grain yield. BR23 was capable of contributing more to grain yield from pre-anthesis assimilation than BR22. The preanthesis assimilate contribution was lowest in Nizersail. 
Table 4: Effect of interaction between cultivar and N on \% pre-anthesis contribution of rice during T. Aman season, 1992.

\begin{tabular}{lllll}
\hline Plant Characters Nitrogen level (kg/ha) & \multicolumn{3}{c}{ Variety } \\
\cline { 3 - 5 } & BR22 & BR23 & Nizersail \\
\hline
\end{tabular}

Stem wt. at anthesis

(t/ha)

$\begin{array}{rlll}0 & 4.18 \mathrm{dC} & 6.01 \mathrm{dA} & 4.89 \mathrm{cB} \\ 60 & 5.62 \mathrm{cA} & 6.63 \mathrm{cdA} & 6.07 \mathrm{bA} \\ 80 & 6.73 \mathrm{bA} & 7.23 \mathrm{bcA} & 7.03 \mathrm{abA} \\ 100 & 7.41 \mathrm{abA} & 7.73 \mathrm{bA} & 7.41 \mathrm{aA} \\ 120 & 7.95 \mathrm{aB} & 8.28 \mathrm{aA} & 7.76 \mathrm{aB}\end{array}$

Straw wt. at harvest

(t/ha)

$\begin{array}{rlll}0 & 3.42 \mathrm{~dB} & 5.06 \mathrm{cA} & 4.54 \mathrm{cA} \\ 60 & 5.00 \mathrm{cA} & 5.57 \mathrm{cA} & 5.70 \mathrm{bA} \\ 80 & 6.07 \mathrm{bA} & 5.82 \mathrm{cA} & 6.78 \mathrm{aA} \\ 100 & 6.87 \mathrm{abA} & 7.35 \mathrm{bA} & 7.26 \mathrm{aA} \\ 120 & 7.74 \mathrm{aB} & 8.07 \mathrm{aA} & 7.68 \mathrm{aB}\end{array}$

Grain yield (t/ha)

$\begin{array}{rlll}0 & 2.66 \mathrm{bB} & 3.37 \mathrm{dA} & 2.75 \mathrm{cB} \\ 60 & 3.66 \mathrm{~dB} & 4.81 \mathrm{cA} & 3.58 \mathrm{aB} \\ 80 & 4.75 \mathrm{cB} & 5.25 \mathrm{cA} & 3.36 \mathrm{abc} \\ 100 & 5.42 \mathrm{bA} & 5.70 \mathrm{bA} & 3.06 \mathrm{bcB} \\ 120 & 6.20 \mathrm{aA} & 6.26 \mathrm{aA} & 2.65 \mathrm{cB}\end{array}$

Pre-anthesis

contribution(\%)

\begin{tabular}{rlll}
0 & $28.18 \mathrm{aA}$ & $28.14 \mathrm{aA}$ & $12.88 \mathrm{aB}$ \\
60 & $17.08 \mathrm{bA}$ & $19.62 \mathrm{bA}$ & $10.48 \mathrm{abB}$ \\
80 & $13.94 \mathrm{bB}$ & $27.37 \mathrm{aA}$ & $7.66 \mathrm{bcC}$ \\
100 & $9.95 \mathrm{cA}$ & $6.54 \mathrm{cAB}$ & $5.03 \mathrm{cdB}$ \\
120 & $3.4 .3 \mathrm{dA}$ & $3.37 \mathrm{cA}$ & $3.02 \mathrm{dA}$ \\
\hline
\end{tabular}

Means in columns and rows followed by the same letter(s) are not significantly different at $5 \%$ level by DMRT. Lower case and capital letters indicate comparison within column and row respectively. 


\section{References}

1. Barker R. \& Robertw H. (1985). The rice economy of Asia. International Rice Research Institute, Los Banos, Philippines.

2. Murayama N. (1979). Nitrogen and rice. International Rice Research Institute, Los Banos, Philippines.

3. Bangladesh Bureau of Statistics (1990). Statistical year book of Bangladesh. Statistical Division, Ministry of Planning, Govt. of the People's Republic of Bangladesh.

4. Bangladesh Rice Research Institute (1993). Proceedings of the workshop on experiences with modern rice cultivation in Bangladesh. Bangladesh Rice Research Institute. p.19.

5. Willey R.W. \& Holliday R. (1971). Plant population and shading studies in barley. Journal of Agricultural Sciences (Camb.). 77: 445-457

6. Gent M.P.N. (1994). Photosynthate reserves during grain filling in winter wheat. Agronomy Journal 86:159-167.

7. Weng J.H., Takedal T., Agata W. \& Hakoyama S. (1982). Studies on dry matter and grain production in rice plant. Japanese Journal of Crop Sciences 51(4): 500-528.

8. Bangladesh Rice Research Institute (1991). Adhunick Dhanear Chash (in Bangla). Bangladesh Rice Research Institute, Gazipur, Bangladesh. Publication No.5 p 25.

9. Makunga O.H.D., Pearman S.M., Thomas M. \& Thorne G.N. (1978). Distribution of photosynthate produced before and after anthesis in tall and semi-dwarf winter wheat, as affected by nitrogen fertilizer. Annals of Applied Biology 88(3): 429-437.

10. Yoshida S. \& Ahn S.P. (1968). The accumulation process of carbohydrate in rice varieties in relation to their response to nitrogen in the tropics. Soil Science and Plant Nutrition 14: 153-162.

11. Gallagher J.N., Bisscoe P.V. \& Scott R.K. (1975). Barley and its environment. V. Stability of grain weight. Journal of Applied Ecology 12: 319-336.

12. Sadeque M.A. (1990). Contribution of pre- and post-anthesis stem reserves and grain yield of barley (Hordeum vulgare L.) as influenced by agronomic practices. Bangladesh Agronomy Journal 3 (1\&2): 20-24. 
13. Gomez K. \& Gomez A.A. (1984). Statistical procedures for agricultural research 2 nd ed. John Wiley and Sons. New York.

14. Jashim C., Ahmed U. \& Ahmed K.U. (1984). Response of rice varieties to applied nitrogen in saline soils. International Rice Research Newsletter 9(5): 22 .

15. Awan I.U., Ahmed H.K. \& Gandapur S.U.D. (1984). Effect of different nitrogen applications on rice grain yield. International Rice Research Newsletter 9(6): 26.

16. Dixit R.S. \& Singh M.M. (1979). Response of rice varieties for N levels under rainfed/direct seeded conditions. International Rice Commission Newsletter 28(2): 26-28.

17. Chandranath M.F., Fernando L.H. \& Weeraratna H. (1962). Fertilizer responses of rice in Ceylon. I Effect of methods and time of nitrogen application. Empire Journal of Experimental Agriculture 37(117): 16-26.

18. Jennyc C.C. (1983). Management of nitrogen fertilizer for increased yield and protein content in early maturing rice. In: 25 years of IRRI thesis and dissertations. International Rice Research Institute(IRRI), Manila, Philippines. $\mathrm{P} 25$.

19. Yoshida S. \& Parao F.T. (1976). Climatic influence on yield and yield components of lowland rice in the tropics. Climate and Rice. Los Banos, Philippines, pp. 471-494.

20. Tanaka A., Navasero S.A., Garcia C.V., Parao P.T. \& Raamierz E. (1968). Growth habit of the rice plant in the tropics and its effects on nitrogen response. International Rice Research Institute. Technical Bulletin 3: 6780 .

21. Mia M.A.J. \& Eunus M. (1974). Effect of NPK doses on rice cultivars. M.Sc. (Ag) Thesis. Bangladesh Agricultural University, Mymensingh p. 35.

22. Bangladesh Rice Research Institute (1992). Annual. Report for 1991. Bangladesh Rice Research Institute, Gazipur, Soil and Fertilizer Management Programme, IV 9-10.

23. Eaqub M., Bhuiyan Z.H. \& Rahman L. (1982). Effect of N, P, K, S and Zn on the yield and chemical composition of HYV rice. M.Sc. (Ag.) Thesis, Bangladesh Agricultural University, pp. 35-62. 
24. Vorob'ev N.V. \& Shazheinnik M.M. (1989). Accumulation of non-structural carbohydrate in rice stem and their mobilization during grain filling. Fiziologiyai Birkhimiya Kul'turnykh Institute, Risa, Krasnodar, USSR. Rice Abstracts 12(3): 157.

25. Prabakar B.S., Preeman W.H. \& Saxenna N.P. (1977). Relative contribution of pre-anthesis and post anthesis photobymeties to grain yield in rice. Andhra Agricultural Journal, India 24(3\&4) : 63-68.

26. Balkema-Boomstra A.G. (1993). The relation between grain yield and some related traits of spring barley (Hordeum vulgare L.) and their usefulness in a breeding program. Euphytica 65(2): 99-106. 